\title{
Cross-Coupling of Organosilanes with Organic Halides Mediated by Palladium Catalyst and TASF
}

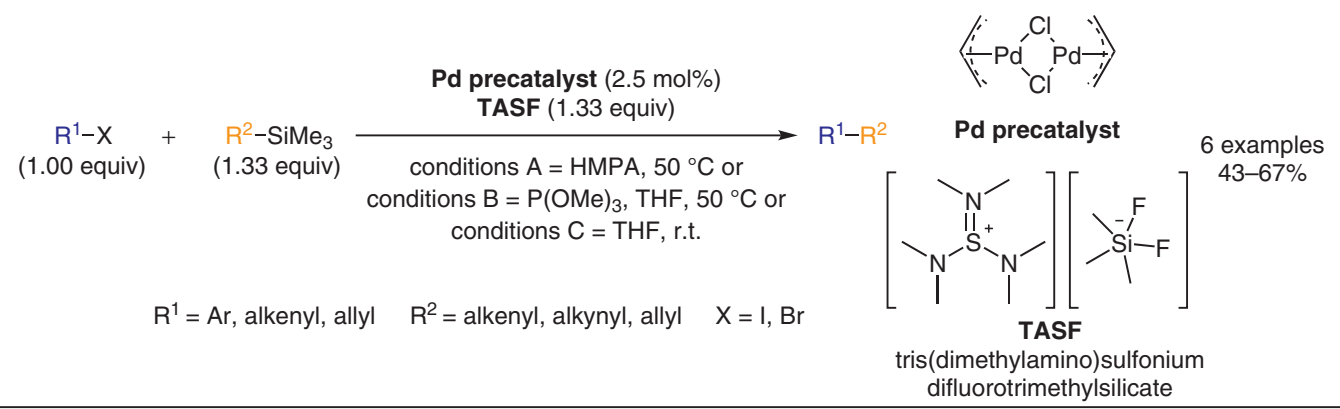

\begin{abstract}
Selected examples:
\end{abstract}<smiles>C=Cc1cccc2ccccc12</smiles>

$$
98 \% \text { yield }
$$
conditions A $\mathrm{X}=\mathrm{I}$<smiles>C=C/C=C/CC=O</smiles><smiles>CCCC=CC=CCOC(C)=O</smiles>

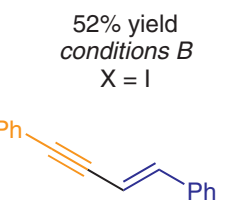

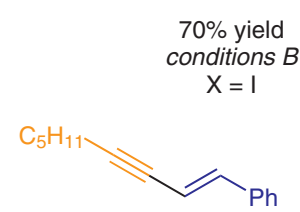

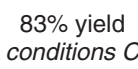
conditions $C$ $\mathrm{X}=\mathrm{Br}$<smiles>C=Cc1ccc([N+](=O)[O-])cc1</smiles>

$$
83 \% \text { yield }
$$
conditions A $\mathrm{X}=\mathrm{I}$<smiles>C=Cc1ccc(N)cc1</smiles>

$85 \%$ yield conditions A $\mathrm{X}=\mathrm{I}$<smiles>C=Cc1ccc(C(C)=O)cc1</smiles>

$86 \%$ yield conditions $A$ $\mathrm{X}=\mathrm{I}$<smiles>C=C/C=C/c1ccccc1</smiles><smiles>C=C/C=C\c1ccccc1</smiles>

\section{$76 \%$ yield} conditions $B$ $X=1$<smiles>C1CCOCC1</smiles><smiles>CC#C/C=C/c1ccccc1</smiles>

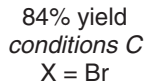<smiles>C(/C=C/c1ccccc1)=C\c1ccccc1</smiles>

93\% yield conditions $B$ $X=1$

$$
32 \% \text { yield }
$$
conditions $B$ $X=1$<smiles>C=CC/C=C/c1ccccc1</smiles>

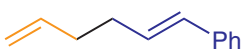

$$
\begin{gathered}
26 \% \text { yield } \\
\text { conditions C } \\
\mathrm{X}=\mathrm{Br}
\end{gathered}
$$

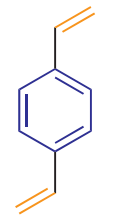

$84 \%$ yield conditions $A$ $\mathrm{X}=\mathrm{I}$
Significance: In 1988, the authors reported a catalytic coupling of simple trimethylsilanes and organohalides in a process that is now known as Hiyama cross-coupling. Organosilanes are stable, easy to handle coupling partners that have low toxicity and good solubility. In addition to trialkylsilanes, trialkoxysilanes and fluoroalkylsilanes are also competent coupling partners. However, a stable C-Si bond requires activation, which is most commonly performed by using a $\mathrm{F}^{-}$source.
Comment: In this first report coupling proceeded under relatively mild conditions and sensitive products were obtained. However, the scope of organosilanes was very limited. Today, many protocols exist for coupling of organosilanes. Those that are fluoride-free are especially useful and desirable. The commercial availability of organosilanes remains a limiting factor in the widespread use of Hiyama coupling.

Review: Y. Nakao, T. Hiyama Chem. Soc. Rev. 2011, 40, 4893-4901. 